A LEVER LONG ENOUGH 



\section{ROBERT MCCAUGHEY}

\section{A LEVER LONG \\ ENOUGH}

A History of Columbia's School of Engineering and Applied Science Since 1864 
Columbia University Press

Publishers Since 1893

New York Chichester, West Sussex

cup.columbia.edu

Copyright (C) 20I4 Columbia University Press

All rights reserved

Library of Congress Cataloging-in-Publication Data

McCaughey, Robert A.

A lever long enough : a history of Columbia's School of Engineering and Applied Science since I864 / Rober McCaughey.

pages $\mathrm{cm}$

ISBN 978-o-23I-I6688-I (cloth : alk. paper) Đ ISBN 978-o-23I-53752-o (ebook)

r. Fu Foundation School of Engineering and Applied ScienceĐ History. I. Title.

$\mathrm{T}_{17 \mathrm{I} . \mathrm{F} 854 \mathrm{M}_{33} 2 \mathrm{OI} 4}$

$620.0071^{\prime} 1747 \mathrm{ID} \mathrm{dc} 23$

2014007037

Columbia University Press books are printed on permanent and durable acid-free paper.

This book is printed on paper with recycled content.

Printed in the United States of America

c Io 98765432 I

Cover Design: Faceout Studio

cover image: General Research Division, The New York Public Library, Astor, Lenox, and Tilden Foundations

References to websites (URLs) were accurate at the time of writing. Neither the author nor Columbia University Press is responsible for URLs that may have expired or changed since the manuscript was prepared. 
To Ann, as always,

to River and Bode, Wyatt and Fiona, and to Columbia's engineers 

Give me a lever long enough and somewhere to stand and I will move the world.

-ARCHIMEDES (287-212 B.c.) $)^{1}$ 
